\title{
NON-VERBAL COMMUNICATION: ASPECTS OBSERVED DURING NURSING CONSULTATIONS WITH BLIND PATIENTS
}

\author{
Comunicação não-verbal: Aspectos Observados Durante \\ a Consulta de Enfermagem com o Paciente Cego \\ Comunicación no-verbal: Aspectos Observados Durante \\ la Consulta de Enfermería con el Paciente Ciego
}

Cristiana Brasil de Almeida Rebouças

Lorita Marlena Freitag Pagliuca

Paulo César de Almeida

\begin{abstract}
Exploratory-descriptive study on non-verbal communication among nurses and blind patients during nursing consultations to diabetes patients, based on Hall's theoretical reference framework. Data were collected by recording the consultations. The recordings were analyzed every fifteen seconds, totaling 1,131 non-verbal communication moments. The analysis shows intimate distance (91.0\%) and seated position (98.3\%); no contact occurred in $83.3 \%$ of the interactions. Emblematic gestures were present, including hand movements (67.4\%); looks deviated from the interlocutor (52.8\%), and centered on the interlocutor (44.4\%). In all recordings, considerable interference occurred at the moment of nurse-patient interaction. Nurses need to know about and deepen non-verbal communication studies and adequate its use to the type of patients attended during the consultations.
\end{abstract}

Keywords: Communication Nonverbal. Nursing. Blindness.

\section{Resumo}

Estudo exploratório-descritivo sobre comunicação nãoverbal entre o enfermeiro e o cego durante a consulta de enfermagem ao diabético, a partir do referencial teórico de Hall. Coleta de dados com filmagem da consulta, analisadas a cada quinze segundos, totalizando 1.131 momentos de comunicação não-verbal. A análise mostra distância íntima $(91,0 \%)$ e postura sentada (98,3\%); em 83,3\% das interações não houve contato. Esteve presente o gesto emblemático de mover as mãos $(67,4 \%)$; o olhar desviado do interlocutor, $(52,8 \%)$ e o olhar centrado no interlocutor $(44,4 \%)$. Em todas as filmagens, houve interferências consideráveis no momento da interação enfermeiro-paciente. Concluise, que o enfermeiro precisa conhecer e aprofundar os estudos em comunicação não-verbal e adequar o seu uso ao tipo de pacientes assistidos durante as consultas.

\section{Resumen}

Estudio exploratorio y descriptivo sobre comunicación noverbal entre el enfermero y el paciente ciego durante la consulta de enfermería al diabético, desde el referencial teórico de Hall. Colecta de datos con filmación de la consulta, analizadas a cada quince segundos, totalizando 1.131 momentos de comunicación no-verbal. El análisis muestra alejamiento íntimo $(91,0 \%)$ y postura sentada $(98,3 \%)$, en $83,3 \%$ de las intervenciones no hubo contacto. Estubo presente el gesto emblemático mover las manos $(67,4 \%)$; el mirar desviado del interlocutor $(52,8 \%$ ) y al mirar centrado en el interlocutor $(44,4 \%)$. En todas las filmaciones, hubieron interferencias considerables en el momento de la interacción enfermero y paciente. Concluyese que el enfermero precisa conocer y profundizar los estudios en comunicación no-verbal y adecuar su utilización al tipo de pacientes asistidos durante las consultas.
Palavras-chave:

Comunicação Não-verbal. Enfermagem. Cegueira.
Palabras clave:

Comunicación No verbal. Enfermería. Ceguera. 


\section{INTRODUCTION}

In all manifestations of life, communication is present and represents an essential element for interaction between human beings. The communication process is a basic instrument in social experience. Thus, for communication to occur, comprehension must exist as, this way, ideas, images and experiences will be moved to a common area ${ }^{(1)}$. In this process, social relations are established, understood in interpersonal communication, where experiences, feelings, emotions and discoveries are exchanged. Basically, communication can be classified as verbal and non-verbal (2). While verbal communication is completely voluntary, the non-verbal type can be an involuntary reaction or an intentional communicative act.

Non-verbal communication refers to messages sent by human actions and behaviors instead of words, representing the majority of messages sent and received, through facial expressions, mannerisms, voice, attitude and clothing. This kind of communication mainly occurs in personal meetings.

Non-verbal signs can be categorized as follows: kinetic, proxemic and paralinguistic. Kinetics studies body movements, proxemics studies body position and spatial relations and paralanguage focuses on the study of the voice and vocalization. Many non-verbal behaviors are interrelated in a message, as one single body movement in itself rarely communicates a meaning (3).

In nursing care delivery to patients, communication will facilitate the achievement of care objectives ${ }^{(4)}$. Communication should be seen in the relationship context it occurs in, as it is meaningless when removed from its context. It must be planned according to the clients, each interaction and each person in particular.

In consultations to blind people, nurses can adopt therapeutic techniques, such as using silence for example, as non-verbal communication also occurs at these moments and validates messages sent and received by both sides. In this interaction, seeing nurses perceive both the verbal and non-verbal communication sent by the blind. However, these professionals should pay attention to their gestual expression, because the non-verbal signs they send to the blind do not refer to what they are verbally expressing. On the other hand, the non-verbal signs sent by the blind can have a different meaning for a seeing person, as it will depend on the social context and visual experiences or not which people live across life.

Visual impairment can hinder the nurse-patient relationship and jeopardize these professionals' work in patient orientation, treatment adherence, understanding and interpretation of communication. It interferes with nurseblind patient communication, as vision is one of the main senses in the reception of non-verbal communication. Thus, this study aimed to analyze nurses' non-verbal communication with blind patients during nursing consultations ${ }^{(7)}$.

\section{THEORETICAL FRAMEWORK}

Scholars have studied non-verbal communication, also known as the theory of non-verbal signs. In this study, Hall's Theory of Proxemics ${ }^{(6)}$ was chosen, which assesses individuals' body posture and spatial relations as an elaboration of the culture they are inserted in.

This theory recommends eight analytic factors, which constitute its primary categories: 1) Posture-gender: participants' gender and interlocutors' basic position (standing, seated, lying). 2) Sociofugal-sociopetal axis: while the former discourages interaction, sociopetal implies the opposite; the shoulders' angle is analyzed in relation to the other person, and the interlocutors' position as face to face, back turned or in any other angle. 3) Kinesthetic: short-distance physical contact, such as touching or brushing the skin and the positioning of body parts. 4) Contact behavior: tactile relations, such as caressing, grabbing, feeling, prolonged holding, pressing against, spot touching, accidental brushing or no physical contact. 5) Visual code: the visual contact mode in interactions, such as eye-to-eye, or the absence of contact. 6) Thermal code: heat perceived by the interlocutors. 7) Olfactory code: characteristics and degree of odor perceived by the interlocutors. 8) Voice loudness: interlocutors' perception of voice volume and intensity.

Besides studying various types of signs and distinctive traits related to the use of space in human relations, proxemics considers four interpersonal distances: intimate distance (from 0 to $50 \mathrm{~cm}$ ), involving physical contact, human warmth, transmission of odors and the most intimate personal meetings; personal distance (from $50 \mathrm{~cm}$ to $1.20 \mathrm{~m}$ ): although close, physical contact may not occur and odors and body warmth may no longer be felt. In social distance $(1.20 \mathrm{~m}$ to $3.60 \mathrm{~m})$, there is no physical contact, but visual contact with the interlocutor; public distance (more than $3.60 \mathrm{~m}$ ) occurs in public speaking and conferences, with no individual but collective visual contact.

\section{METHODS}

This exploratory, descriptive and quantitative study analyzed non-verbal communication between nurses and blind patients in order to support interventions and quality improvements in care delivery to these clients. The project was elaborated according to the National Health Council guidelines for research involving human beings, as established in Resolution 196/96 by the Brazilian Ministry of Health ${ }^{(6)}$, and approved under protocol No. 327/04. Data collection started after nurses, blind patients and their companions had signed the Free and Informed Consent Term.

The research was carried out at a secondary health unit in Fortaleza-CE, which is a state referral institution for diabetes and hypertension care ${ }^{(5)}$. Nurses were included if they delivered care to diabetes patients, a disease that can cause eye diseases like cataract, glaucoma and diabetic retinopathy. The choice of this service is justified by the fact that blind 
diabetics were followed-up at the institution. These blind diabetes patients were selected through a convenience sample, including patients with a medical diagnosis of blindness, who were attended by nurses who agreed to participate in the research. Inclusion criteria were blindness and age over 18, considering ethics and aptitude for decision making.

Data were collected between February and April 2005, using a camera to film the nursing consultations between the nurse and the blind patient. Thus, non-verbal data were filed for analysis. Recordings were made at the nursing consultation room. The camera was strategically positioned on a fixed tripod. During care, one researcher remained inside the consultation room, without interfering with communication.

The data analysis instrument to assess nurses' non-verbal communication with the blind was elaborated on the basis of Hall's theoretical reference framework ${ }^{(7)}$ and was called NonVerbal Nurse-Blind Communication (CONVENCE) ${ }^{(8)}$. The CONVENCE assesses Spatial Distance, as the first category or variable, divided in four subcategories. These are: 1 . Distance, classified as intimate, personal, social and public; 2. Posture, delimited as: standing, seated, lying; 3 . Axis, identified as: faceto-face, back turned, another angle, sociofugal and sociopetal; 4. Contact, called: touching, caressing, grabbing, feeling, prolonged holding, pressing against, spot touching, accidental brushing and no physical contact. The second category, social behavior, was subdivided into: 1. Emblematic gestures, classified as resisting, moving hands and others; 2 . Illustrating gestures: either complementing verbal communication or not; 3 . Regulating gestures: head nods, eye movements and others. The third category, called Facial Behavior, contained: perplexity, disgust, joy, fear, anger, sadness and others. The fourth category, Visual Code, covered two subdivisions of Eye opening: surprise, joy, sadness and others; and Eye direction: centered on or deviated from the speaker. The fifth, Voice Loudness, was classified as whispering, yelling, normal and silence.

The recordings were analyzed by three experts, who watched the films and assessed the non-verbal categories of the communication instrument. Agreement levels among the experts' answers ranged around $80 \%$. Researchers adopt this rate, including because subjectivity in this research line never allows for clear-cut reliability among experts ${ }^{(8)}$.

All experts saw the full version of the film and, after this phase, analyzed it as previously established. Data were analyzed as absolute frequencies through a univariate table with relative frequencies and percentages, processed in Stats Direct (ST) software.

\section{RESULTS}

We analyzed five consultations, realized by four nurses. Each recording was analyzed every fifteen seconds, totaling a sample of 1,131 non-verbal communication analyses. The mean duration of the recordings was nineteen minutes, ranging between fifteen and twenty-four minutes.

Table 1 shows absolute frequencies and percentages of non-verbal sign categories analyzed through the CONVENCE.
TABLE 1

Univariate synthesis of non-verbal communication categories according to Hall (6)

\begin{tabular}{|c|c|c|}
\hline CATEGORIES & NUMBERS & $\%$ \\
\hline $\begin{array}{l}\text { 1. SPATIAL DISTANCE } \\
\text { 1.1 Distance } \\
\text { Intimate } \\
\text { Personal } \\
\text { Absent }\end{array}$ & $\begin{array}{c}1,030 \\
89 \\
12\end{array}$ & $\begin{array}{l}91.0 \\
7.9 \\
1.1\end{array}$ \\
\hline $\begin{array}{l}\text { 1.2 Posture } \\
\text { Seated } \\
\text { Absent/ Other }\end{array}$ & $\begin{array}{c}1,112 \\
19\end{array}$ & $\begin{array}{r}98.3 \\
1.7\end{array}$ \\
\hline $\begin{array}{l}\text { 1.3 Axis } \\
\text { 1.3.1 Axis/ Position } \\
\text { Another angle } \\
\text { Face to face } \\
\text { Absent/ Other }\end{array}$ & $\begin{array}{c}645 \\
445 \\
41\end{array}$ & $\begin{array}{r}57.0 \\
39.3 \\
3.7\end{array}$ \\
\hline $\begin{array}{l}\text { 1.3.2 Axis / Interaction } \\
\text { Sociopetal } \\
\text { Sociofugal } \\
\text { Absent/ Other }\end{array}$ & $\begin{array}{c}892 \\
203 \\
36\end{array}$ & $\begin{array}{r}78.9 \\
18.0 \\
3.1\end{array}$ \\
\hline $\begin{array}{l}\text { 1.4 Contact } \\
\text { No Contact } \\
\text { Localized touch } \\
\text { Absent/ Other }\end{array}$ & $\begin{array}{c}943 \\
140 \\
48\end{array}$ & $\begin{array}{r}83.3 \\
12.4 \\
4.3\end{array}$ \\
\hline $\begin{array}{l}\text { 2. SOCIAL BEHAVIOR } \\
\text { 2.1 Emblematic gestures } \\
\text { Moving the hands } \\
\text { Not observed/ No contact } \\
\text { Absent/ Other }\end{array}$ & $\begin{array}{l}762 \\
247 \\
122\end{array}$ & $\begin{array}{l}67.4 \\
21.8 \\
10.8\end{array}$ \\
\hline $\begin{array}{l}\text { 2.2 Illustrating gestures } \\
\text { Complement the verbal one } \\
\text { Do not complement the verbal one } \\
\text { Absent/ Other }\end{array}$ & $\begin{array}{c}566 \\
510 \\
55\end{array}$ & $\begin{array}{r}50.0 \\
45.1 \\
4.9\end{array}$ \\
\hline $\begin{array}{l}\text { 2.3 Regulating gestures } \\
\text { Not observed/ No contact } \\
\text { Eye movement } \\
\text { Head nod } \\
\text { Absent/ Other }\end{array}$ & $\begin{array}{l}582 \\
273 \\
176 \\
100\end{array}$ & $\begin{array}{r}51.4 \\
24.1 \\
15.6 \\
8.9\end{array}$ \\
\hline $\begin{array}{l}\text { 3. FACIAL BEHAVIOR } \\
\text { Not observed/ No contact } \\
\text { Attention } \\
\text { Joy } \\
\text { Absent/ Other }\end{array}$ & $\begin{array}{c}499 \\
155 \\
97 \\
380\end{array}$ & $\begin{array}{r}44,1 \\
13.7 \\
8.6 \\
33.6\end{array}$ \\
\hline $\begin{array}{l}\text { 4. VISUAL CODE } \\
\text { 4.1 Ocular Opening } \\
\text { Not observed/ No contact } \\
\text { Joy } \\
\text { Attention } \\
\text { Absent/ Other }\end{array}$ & $\begin{array}{c}873 \\
53 \\
51 \\
154\end{array}$ & $\begin{array}{r}77.2 \\
4.7 \\
4.5 \\
13.6\end{array}$ \\
\hline $\begin{array}{l}\text { 4.2 Eye Direction } \\
\text { Deviated from the speaker } \\
\text { Centered on the speaker } \\
\text { Absent/ Other }\end{array}$ & $\begin{array}{c}597 \\
502 \\
32\end{array}$ & $\begin{array}{r}52.8 \\
44.4 \\
2.8\end{array}$ \\
\hline $\begin{array}{l}\text { 5. VOICE VOLUME } \\
\text { Normal } \\
\text { Silent } \\
\text { Absent/ Other }\end{array}$ & $\begin{array}{c}746 \\
365 \\
20\end{array}$ & $\begin{array}{r}66.0 \\
32.3 \\
1.7\end{array}$ \\
\hline TOTAL & 1,131 & 100.0 \\
\hline
\end{tabular}




\section{DISCUSSION}

Blind people are entitled to receive specialized nursing care. For this care to be successful, nurses need to develop specific skills for communicating with the blind. This can preserve and increase the efficacy of health care ${ }^{(5)}$. As mentioned above, nonverbal communication allows for the direct expression of feelings and emotions, and its functions are to complement, contradict and replace verbal communication ${ }^{(9)}$.

During interpersonal relations, like in nursing consultations, the expression of these non-verbal signs can be perceived. The distances maintained in an interaction can vary according to the people's culture and characteristics (gender, stature). The ideal distance for Latinos and Europeans to hold a dialogue is different. A very close distance can be considered an invasion of one's intimacy, while too far a distance can be interpreted as a lack of interest.

Experts disagreed about voice loudness and the subcategories emblematic and regulatory gestures and ocular opening. It can be inferred that this result derived from the large number of non-observed answers during the scenes. Voice loudness refers to a more subjective answer as, according to one expert, the nurse was talking normally, while another considered she was whispering and vice-versa. Moreover, loudness was influenced by the recording technique and the type of environment, as recordings were made in the actual consultation environment.

As to Spatial Distance, intimate distance (91\%) prevailed, followed by personal distance $(7.9 \%)$ and cases in which the nurse was not seen or did not appear in the image (1.1\%). The nurse should keep a distance that demonstrates interest (10). Na attitude capable of inducing approximation can be very important during an initial contact, when the nurse-patient relation does not exist yet ${ }^{(11)}$.

During consultations, the seated position was predominant $(98.3 \%)$ in the analyzed images. When the sender and the receiver maintain the same attitude, this means that they are in tune, sharing the same rhythm, level of interest and movement. Posture reveals the type of relation established with the other, demonstrating mastering or submission, territoriality, intensity of the relationship and attempts to strengthen the bond ${ }^{(5)}$. During nursing consultations, the seated position is comfortable to realize anamnesis, record in the patient file what the patient is saying and expressing, measuring glucose levels and checking blood pressure. Literature recommends that the adequate posture should manifest availability ${ }^{(10)}$.

Body position reflects thoughts and feelings. The latter are communicated through the language of behavior ${ }^{(12)}$. As to the axis/ position, $57 \%$ of interactions were related to another angle, $39.3 \%$ to the face-to-face position, and absent/other in $3.7 \%$. As to the position of the shoulders towards the other person, among the total number of interactions, $78.9 \%$ demonstrated encouragement or were sociopetal, $18 \%$ showed discouragement or were sociofugal, and this aspect was absent in $3.1 \%$. In a restricted environment, one tends to look at the other person less ${ }^{(9)}$. Therefore, the most detected positions during consultations were different angles between sender and receiver.
The assessment of contact showed interactions without any contact $(83.3 \%$ ), but localized touch or touch occurred in $12.4 \%$. Human beings' contact with the world starts through the senses, which are capable of transmitting pleasure and displeasure ${ }^{(13)}$.

Touching objects makes it possible to get a precise perception of their forms and textures. This feeling is not only limited to the hand, but extends throughout the human body (13). Among all sensations, touch is experienced most personally and can be defined as the skin's faculty to issue and detect feelings. As it is extraordinarily developed, it is believed that, in the past, touch provided a decisive contribution to the survival of mankind. And it still performs a certain role in this respect. Blind people, for example, perceive daylight or cold at night through thermal sensations ${ }^{(6)}$.

Touch can have different meanings for nurses as well as for patients. When used as a care humanization object, it can become a source of support to minimize patients' suffering and create affective bonding, with a view to delivering a better form of care ${ }^{(14)}$. A firm and secure touch is worth more than words ${ }^{(15)}$. Nurses need to be aware of the importance of this resource in care humanization for clients and should use it effectively, in order to avoid turning it into a mechanical act, a source of distancing between nurses and patients and a barrier in the communication process.

Social Behavior includes emblematic, illustrating and regulatory gestures. Emblematic gestures are cultural, learned and can directly express what is verbally pronounced. These gestures are supported by different body parts, mainly the upper limbs and the head. The characteristics of this gestuality are present in a wide range of cultures ${ }^{(9)}$. In this research, the most observed gesture was moving one's hands (67.4\%).

People move their hands when they face difficulties to express themselves or when their efforts to make themselves understood are enormous ${ }^{(16)}$. Nurses gesticulated to try and make the blind patient understand what was being expressed. As blind patients do not have visual capacity, these professionals need to pay attention to explore other communication forms.

Illustrating gestures are learned through imitation. They accompany discourse by emphasizing a pronounced word or sentence ${ }^{(9)}$. This type of gestures refers to the signs sent by the hands and arms. There may be more than 700,000 different signs ${ }^{(16)}$. The nurses' illustrating gestures either complemented (50\%) or did not complement $(45.1 \%)$ verbal communication.

Regulatory gestures regulate and maintain communication among people and guide the sender so as to continue, repeat, elaborate and give opportunity for other persons to speak ${ }^{(16)}$. No contact/ not observed was identified in $51.4 \%$, eye movements in $24.1 \%$ and head nods in $15.6 \%$, while this aspect was absent or other categories were observed in $8.9 \%$. Nodding one's head reinforces the other person's discourse and moving one's eyes towards that person reinforces discourse, while deviating them inhibits. These gestures are at the periphery of our awareness and, therefore, they are difficult to inhibit, ad body movements are involuntary. The rest of the body and its position towards other persons reveal what is unconscious in the individual (10).

The face is the most exposed part of the human body, where emotions are more explicit and more clearly 
demonstrated. The study of human facial expressions is difficult, because movements are often extremely subtle and ephemeral and because they are innate or hereditary, although they can partially be modified by learning or imitation ${ }^{(17)}$.

Some expressions are easily recognizable, but each person can judge them differently, depending on his/her imaginative capacity and way of acting. Expressions are better analyzed when they are not influenced by imagination. Moreover, facial muscles are quite confounding. Their physical structure is very variable, making it difficult to find equal muscles in half a dozen individuals ${ }^{(17)}$. The study of blind and deaf children's facial expressions made it possible to observe smile, laugh, anger and some other fundamental expressions, which demonstrated that these behaviors are innate. Moreover, from a cultural point of view, the main mimic expressions exhibited by people from different countries display important similarities ${ }^{(18)}$.

The nurses' facial expressions during the consultations were either not observed (44.1\%), or showed attention (13.7\%) and joy $(8.6 \%)$, or were absent/other $(33.6 \%)$. Facial expressions are interrelated with the context in which the interaction occurs. The face is also considered as the best "liar" in non-verbal communication, as it is the body area people are most aware of and where control attempts are more constant ${ }^{(9)}$. Face movements grant vivacity and energy to the words, revealing thoughts and intentions better than words themselves ${ }^{(17)}$. Hence, nurses mainly need to observe the patients' face ${ }^{(4)}$.

Blind patients are not capable of visually perceiving what nurses express through their faceo mais explis exposta do ser humano e onde as emoçcesso comunicativo./ APOSTILA_COMN_mpreender o mundo d. Nurses, however, can assess the efficacy of their communication with patients by observing their facial expressions. However, the blind's facial expression can be poor in communicative terms, as they do not perceive the other person's expressions, causing difficulties to communicate these expressions ${ }^{(19)}$. But it is through this understanding that patients' real needs are assessed and an individualized action plan can be programmed, considering the person as a whole ${ }^{(20)}$. Hence, further knowledge about non-verbal communication is needed with a view to an effective interpersonal relationship.

Looks also deserve emphasis in the human face, due to the wide range of signs they can issue ${ }^{(21)}$. The Visual Code category is analyzed by ocular opening and eye direction. In this study, only nurses were observed in this sense, as blind people do not react to this stimulus. Thus, either contact was not observed or did not occur $(77.2 \%)$, or the films showed joy $(4.7 \%)$, attention (4.5\%), and absent/other (13.9\%). Looks can pass countless messages, including interest, disinterest, encouragement, attention and joy, and can even define domain. Another important function of looks is to establish and regulate the conversation flow ${ }^{(22)}$.

The eyes often reveal what is hidden in the soul and can arouse emotive feelings like love, sympathy, enthusiasm and tiredness ${ }^{(23)}$. The eye direction subcategory registered: deviated from the interlocutor $(52.8 \%)$, centered on the interlocutor $(44.4 \%)$ and absent $(2.8 \%)$. It is known that maintaining visual contact means avoiding to deviate one's look frequently, which does not mean looking fixedly, as good contact suggests interest in listening to the other person. Deviating one's eyes frequently suggests reluctance or discomfort about being with the person. When looks are a bit more intense, this suggests that the person is self-assured, sincere and interactive, which favors the deepening of the interpersonal relation ${ }^{(11)}$. Nurses cannot expect the blind to react to a look, as there exists an obstacle that impedes this visual contact, although this does not mean a lack of interaction and harmony during care ${ }^{(19)}$.

The fifth category contemplated in the analysis of nurses' non-verbal communication with blind patients was Voice Loudness, resulting in: normal tone $(66 \%)$, silence $(32.3 \%)$ and absent/other (1.7\%). Tone of voice and gestures reinforce discourse; they are one of the most elaborate forms of human interaction ${ }^{(12)}$. The act of listening to other persons is a nonverbal communication attitude inserted in interpersonal relations, which is essential to achieve further understanding among the people involved in the process ${ }^{(24)}$, as human beings are much more talkative than capable of listening ${ }^{(13)}$. Effective listening occurs when the receiver is capable of discerning and understanding the meaning of the message issued by the other ${ }^{(25)}$.

The act of teaching and guiding requires people who learn and know how to listen ${ }^{(26)}$. Active listening is a technique that must be learned and practiced, mainly by professionals dealing with the public, such as nurses in this study ${ }^{(25,26)}$. Nurses need to actively and critically listen to patients with a view to positive communication. Listening requires maintaining silence, demonstrating interest and, mainly, learning how to control feelings, emotions and prejudices ${ }^{(9)}$.

\section{CONCLUSION}

Nurses need to get to know and deepen studies about nonverbal communication theories and adapt its use to the type of clients they attend during consultations. These professionals should assess their behavior, gestures and attitudes, in short, their non-verbal communication, with a view to making effective interventions involving blind patients. Moreover, nurses should obtain deeper knowledge about blind people's behavior in order to decode the non-verbal signs they send, as these can be expressed differently from seeing persons. 


\section{References}

1. Mendes IAC. Enfoque humanístico à comunicação em enfermagem. São Paulo (SP): Sarvier; 1994.

2. Stefanelli MC. Comunicação com o paciente: teoria e ensino. São Paulo (SP): Robe; 1993.

3. Littlejohn SW. Fundamentos teóricos da comunicação humana. Rio de Janeiro (RJ): Guanabara; 1998.

4. Silva LMG, Brasil VV, Guimarães HCQCP, Savonitti BHRA, Silva MJP. Comunicação não-verbal: reflexões acerca da linguagem corporal. Rev Latino- Am Enferm 2000; 8 (4): 52-8.

5. Rebouças CBA. Características da comunicação não-verbal entre o enfermeiro e o cego [dissertação de mestrado]. Fortaleza (CE): Departamento de Enfermagem, Universidade Federal do Ceará; 2005.

6. Resolução $n^{0} 196$, de 10 de outubro de 1996. Dispõe sobre diretrizes e normas regulamentadoras de pesquisa envolvendo seres humanos. Bioética 1996; 4 (supl 2): 15-25.

7. Hall ET. A dimensão oculta. Lisboa(P0): Relógio D'água; 1986.

8. Sawada NO. Dimensão não verbal da interação enfermeiro-paciente em situação pré-operatória. Ribeirão Preto, 1990. 97p. [dissertação de mestrado]. Escola de Enfermagem de Ribeirão Preto/USP; 1990.

9. Silva MJP. Comunicação tem remédio: a comunicação nas relações interpessoais em saúde. São Paulo (SP): Gente; 1996.

10. Landeros LM. Uso de simulação filmada para avaliar 0 relacionamento interpessoal enfermeiro-paciente no cuidado ao adulto hospitalizado [tese de doutorado]. Ribeirão Preto (SP): Escola de Enfermagem de Ribeirão Preto/USP; 2004.

11. Leite AM, Silva IA, Scochi CGS. Comunicação não-verbal: uma contribuição para o aconselhamento em amamentação. Rev LatinoAm Enferm 2004; 12 (2): 258-64.

12. Hall ET. A linguagem silenciosa. Lisboa(P0): Relógio D'água; 1994.

13. Oliveira JVG. Do essencial invisível: arte e beleza entre os cegos. Rio de Janeiro (RJ): Revan / FAPERJ; 2002.

14. Castro RCBR, Tabet K. 0 uso do toque como fator de humanização da assistência de enfermagem em UTI. Anais do $8^{\circ}$ Simpósio Brasileiro de Comunicação em Enfermagem; 2002 maio 2-3, Ribeirão Preto (SP), Brasil. Ribeirão Preto (SP): EERP/USP; 2002.

15. Araújo STC, Porto IS, Santos I, Santoro DC. Os sentidos corporais dos estudantes de enfermagem na aprendizagem sociopoética da comunicação não-verbal do cliente em recepção pré-operatória. Anais do $8^{\circ}$ Simpósio Brasileiro de Comunicação em Enfermagem; 2002 maio 2-3, Ribeirão Preto (SP), Brasil. Ribeirão Preto (SP): EERP/USP; 2002. 16. Davis F. A comunicação não verbal. $4^{\mathrm{a}}$ ed. São Paulo (SP): Summus; 1979.

17. Darwin C. A expressão das emoções no homem e nos animais. São Paulo (SP): Companhia das Letras; 2000.
18. Bitti PR, Zani B. A comunicação como processo social. $2^{\mathrm{a}}$ ed. Lisboa(P0): Estampa; 1997.

19. Barczinski MCC. Reações psicológicas à perda da visão. Rev Benjamin Constant [periódico on-line] 2001 abr; [citado 10 jul 2005]; 1(18): [aprox. 5 telas]. Disponível em: http://www.bc.gov.br/Paginas/ Nossos_Meios/RBC/public/RevAbr2001/Artigo\%203.rtf

20. Silva MJP. Construção e validação de um programa sobre comunicação não verbal para enfermeiros [tese de doutorado]. São Paulo (SP): Escola de Enfermagem/ USP; 1993.

21. Silva MJP. A percepção das enfermeiras sobre a comunicação não verbal dos pacientes [dissertação de mestrado]. São Paulo (SP): Escola de Enfermagem/USP; 1989.

22. Mazza VA. A comunicação não-verbal como forma de cuidado de enfermagem: ensino e prática [dissertação de mestrado]. Curitiba (PR): Departamento de Enfermagem/ UFP; 1998.

23. Peto AC. Terapia através da dança com laringectomizados: relato de experiência. Rev Latino-Am Enferm 2000; 8 (6): 35-9.

24. Braga EM. Competência em comunicação: uma ponte entre aprendizado e ensino na enfermagem [tese de doutorado]. São Paulo (SP): Escola de Enfermagem/USP; 2004.

25. Freire P. Pedagogia da autonomia. Rio de Janeiro (RJ): Paz e Terra; 1997.

26. Guedes MTS, Figueiredo NMA, Nascimento MAL, Ghidini Junior R. Transpondo a barreira do silêncio e da solidão do cliente laringectomizado através das ações de enfermagem. Esc Anna Nery R Enferm 2004 dez; 8(3): 464-69.

\section{Note}

Manuscript derivated of Master Dissertation granted in 2002 (as in reference 5).

\section{About the Authors}

\section{Cristiana Brasil de Almeida Rebouças}

RN. M.Sc., Graduate Nursing Program /UFC. Doctoral Student in Nursing, Ceará Federal University.

\section{Lorita Marlena Freitag Pagliuca}

Full Professor, Nursing Department, UFC. CNPq Researcher. Coordinator of the LabCom_Saúde Project/CNPq.

\section{Paulo César de Almeida}

Professor. PhD in Statistics, UFC. 